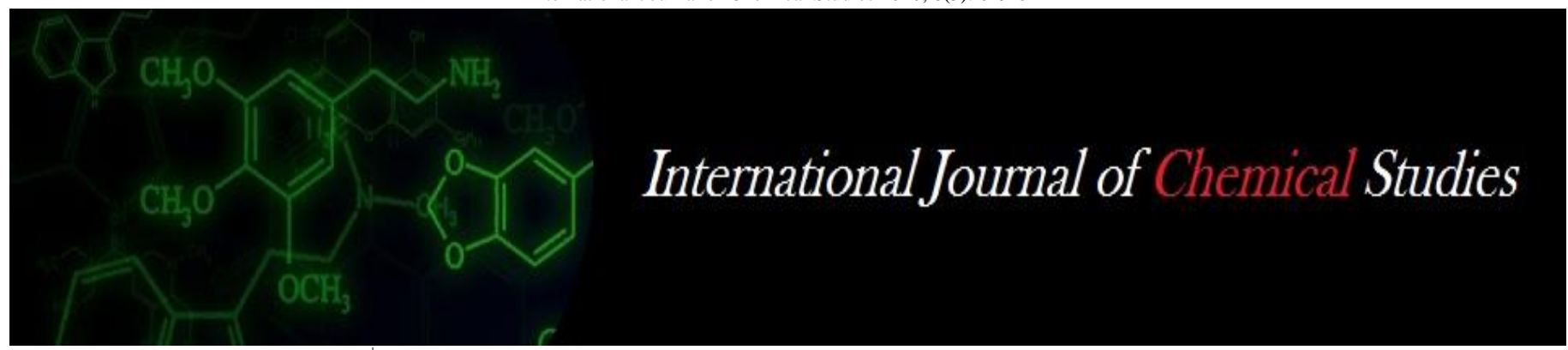

P-ISSN: 2349-8528

E-ISSN: 2321-4902

www.chemijournal.com

IJCS 2020; 8(5): 619-621

(C) 2020 IJCS

Received: 04-06-2020

Accepted: 10-08-2020

\section{Priti Sonkamble}

Associate Professor, Department

of Agricultural Botany, Dr.

Panjabrao Deshmukh Krishi

Vidyapeeth, Akola,

Maharashtra, India

RS Nandanwar

former Head, Department of

Agricultural Botany, Dr.

Panjabrao Deshmukh Krishi

Vidyapeeth, Akola,

Maharashtra, India

SB Sakhare

Associate Professor, Department of Agricultural Botany, Dr.

Panjabrao Deshmukh Krishi

Vidyapeeth, Akola,

Maharashtra, India

\section{PV Jadhav}

Assistant Professor of Agril. Biotechnology, Dr. Panjabrao Deshmukh Krishi Vidyapeeth, Akola, Maharashtra, India

Philips Varghese

Scientist \& Soybean Breeder, Agharkar Research Institute, Pune, Maharashtra, India

Corresponding Author: Priti Sonkamble Associate Professor, Department of Agricultural Botany, Dr. Panjabrao Deshmukh Krishi

Vidyapeeth, Akola,

Maharashtra, India

\section{Assessment of grain and vegetable type soybean genotypes for nutritional composition}

\author{
Priti Sonkamble, RS Nandanwar, SB Sakhare, PV Jadhav and Philips \\ Varghese
}

DOI: https://doi.org/10.22271/chemi.2020.v8.i5i.10362

\begin{abstract}
The present study was conducted to analyse the nutritional composition of fourteen soybean genotypes including seven each of grain and vegetable types. The study revealed that oil content was in the range of 17.51 to $20.59 \%$ at R8 stage, protein $18.11 \%$ to $27.57 \%$ at R6 and $32.57 \%$ to $39.09 \%$ at R8 stage, carbohydrate content at R6 stage 7.43 to $11.08 \mathrm{~g} / 100 \mathrm{~g}$ and 24.15 to $28.37 \mathrm{~g} / 100 \mathrm{~g}$ at R8 stage, sugar content 0.90 to $3.43 \mathrm{~g} / 100 \mathrm{~g}$, iron content at R6 stage 3.24 to $7.12 \mathrm{mg} / 100 \mathrm{~g}$ and $6.79 \mathrm{mg} / 100 \mathrm{~g}$ to 9.79 $\mathrm{mg} / 100 \mathrm{~g}$ at R8 stage, zinc content at R6 stage 4.74 to $6.40 \mathrm{mg} / 100 \mathrm{~g}$ and $3.93 \mathrm{mg} / 100 \mathrm{~g}$ to $5.60 \mathrm{mg} / 100 \mathrm{~g}$, The trypsin inhibitor content was ranged between 18.29 to $46.26 \mathrm{mg} / \mathrm{g}$ and 33.96 to $75.09 \mathrm{mg} / \mathrm{g}$ at R6 and R8 stage respectively. Vegetable types were found more nutritious than grain type soybean. Swarna vasundhara was found promising for protein content at R6 stage, the genotype AGS-450 exhibited high iron with low trypsin content whereas, AGS-459 exhibited high sugar and zinc content.
\end{abstract}

Keywords: Vegetable type, protein, nutritional, quality, soybean

\section{Introduction}

Soybean (Glycine max (L.) Merrill) is an important legume crop in India. Being a legume, it is a unique crop of versatile nutritional attribute, yielding both oil and protein. It contains about $37-42 \%$ of good quality protein, $6 \%$ ash, $29 \%$ carbohydrate and $17-24 \%$ oil comprising $85 \%$ unsaturated fatty acid with two essential fatty acids (lenoleic and linolenic acid) which are not synthesized by the human body, so it is highly desirable in human diet (Aditya et al. 2011) ${ }^{[1]}$. The soybean area in Maharashtra during 2019-2020 was 37.36 lakh ha with the total production of about 39.42 lakh MT and average productivity of about $1055 \mathrm{~kg}$ per hectare (Anonymous, 2019) ${ }^{[2]}$. Soybean can be divided into two categories: vegetable soybean, which is harvested between reproductive stages 6 (R6) and 7 (R7) of growth when the seeds have developed to fill $80 \%-90 \%$ of the pod, and grain soybean, which is harvested at reproductive stage 8 (R8) when the pod has reached full maturity. Grain soybean is primarily used for manufacturing oil and protein products. Vegetable soybean, however, is consumed mainly as a vegetable or snack. Like grain soybean, vegetable soybean is also rich in protein, oil, and other nutritious constituents. Vegetable soybean is good source of vitamin A, carbohydrates, protein and iron and is more nutritious than vegetable green peas ( $\mathrm{Gu}$ et al. 2002) ${ }^{[5]}$. They are usually large-seeded with mild taste, tender and easily digestible. Fresh green soybeans also have a combination of low oil and relatively high protein content. They also contain a lower percentage of gas-producing starches. Harvesting vegetable soybeans at the right time is critical for maximum texture and flavour, because loss of quality occurs when pods turn yellow. The increasing nutritional needs of the growing population can only be met by producing nutritionally rich crop varieties. The nutritional assessment of the present cultivars gives us an idea about the genotypes rich in nutrients. These genotypes can be focused for further improvement by breeders. Realizing the importance of the above facts, the present study was carried out with the objective of assessing the nutritional composition in grain and vegetable type soybean.

\section{Materials and Methods}

The material under study was constituted of seven grain (JS-335, JS (SH) 93-37, JS-93-05, MACS-450, MACS-1037, MACS-1188 and NRC 37) and seven vegetable type (Swarna 
vasundhara, GC-84501-32-01, AGS-339, AGS-450, AGS457, AGS-459 and Himso-1563) soybean genotypes obtained from the germplasm maintained at Dr. Panjabrao Deshmukh Krishi Vidyapeeth, Akola; Asian Vegetable Research and Development Centre (AVRDC), Hyderabad, Jawaharlal Nehru Krishi Vishwavidyalaya, Jabalpur and Agharkar Research Institute, Pune. These genotypes were evaluated for nutritional properties during kharif 2017-2018. Nutritional quality traits of genotypes for oil, protein, carbohydrate, sugar, iron, zinc and trypsin inhibitor content were carried out. The seed oil content was estimated by NMR (Nuclear Magnetic Resonance) spectrophotometer whereas, protein content from soybean seeds at green (R6) stage and maturity stage (R8) estimated using Bradford method (Bradford, 1976) ${ }^{[3]}$ and expressed in percentage. The carbohydrate content was determined by Anthrone reagent and total sugar estimated by using the Phenol sulfuric acid method (Sengar and Chaudhary 2014) ${ }^{[11]}$. Iron and zinc present in the seeds at green stage and grain stage were measured using the Atomic Absorption spectrophotometer (Jackson, 1967) ${ }^{[7]}$. Trypsin inhibitor content was determined according to the standard method of Kakade et al. (1974) ${ }^{[8]}$ as modified by Hammerstrand et al. $(1981)^{[6]}$. Benzoyl-dl-arginine-paranitroanilide (BAPNA) was used as enzyme substrate and the product, p-nitroanilide was measured at $410 \mathrm{~nm}$. The trypsin inhibitor level was expressed as milligram trypsin inhibited per gram sample.

\section{Results and discussion}

The nutritional quality traits were recorded at different growth stages among the soybean genotypes and presented in table 1 and 2. The oil content was recorded at R8 stage and varied from 17.51 to $20.59 \%$. The maximum oil content was observed in JS-335 (20.59\%) which was at par with NRC-37 (20.42\%), JS(SH)93-37 (20.36\%), MACS-1188 (20.11\%), MACS-1037 (20.03\%), Himso-1563 (20.01\%), AGS-339 (19.90\%), JS-93-05 (19.72\%) and MACS-450 (19.51\%) whereas, minimum oil content was recorded in AGS457(17.51\%). Similar results are recorded by Swathi (2009) ${ }^{[13]}$ and Ramya (2015) ${ }^{[10]}$ in soybean.

The protein content at R6 stage was varied from $18.11 \%$ to $27.57 \%$. Swarna vasundhara recorded maximum $(27.57 \%)$ protein content at R6 stage and was found at par with Himso1563 (27.55\%). Whereas, minimum protein content was recorded in JS-93-05(18.11\%) which was at par with MACS$450(18.57 \%)$. However, maximum protein content at R8 stage was found in Himso-1563 (39.09\%) which was at par with NRC-37(38.40\%), AGS-459 (38.38\%) and MACS-1188 $(38.22 \%)$ whereas, genotype AGS-339 recorded minimum $(32.57 \%)$ protein content and it was varied from $32.57 \%$ to $39.09 \%$. The present results are in accordance with the findings of Poornima et al. (2014) ${ }^{[9]}$ and Ramya (2015) ${ }^{[10]}$.

The carbohydrate content at R6 stage ranged between 7.43 to $11.08 \mathrm{~g} / 100 \mathrm{~g}$. The genotype JS(SH)93-37 had highest carbohydrate content $(11.08 \mathrm{~g} / 100 \mathrm{~g})$ at R6 stage and was found at par with JS-335(10.67 g/100g), MACS-450(10.11 g/100g),MACS-1188(10.05g/100g),JS-93-05 (9.89 g/100g), NRC-37(9.44 g/100g) and MACS-1037(9.23 g/100g). The lowest carbohydrate content was observed in genotype GC84501(7.43 g/100g) which was at par with Himso-1563 (7.70 $\mathrm{g} / 100 \mathrm{~g})$, Swarna vasundhara $(7.76 \mathrm{~g} / 100 \mathrm{~g})$ and AGS-339 $(8.13 \mathrm{~g} / 100 \mathrm{~g})$. Maximum carbohydrate content at R8 stage was found in AGS-459 (28.37 g/100g) which was at par with Swarna vasundhara (28.30 g/100g), JS(SH)93-37 (27.59 $\mathrm{g} / 100 \mathrm{~g})$. The genotype JS-93-05 recorded lowest carbohydrate content $(24.15 \mathrm{~g} / 100 \mathrm{~g})$ and was at par with
MACS-1037(24.41 g/100g). The carbohydrate content at R8 stage was varied from 24.15 to $28.37 \mathrm{~g} / 100 \mathrm{~g}$.

Maximum sugar content at R6-R7 stage was observed in AGS-459 (3.43 g/100g) which was at par with AGS-457 (3.13 $\mathrm{g} / 100 \mathrm{~g})$, AGS-450 $(2.77 \mathrm{~g} / 100 \mathrm{~g})$ and Swarna vasundhara (2.57 g/100g), However, minimum sugar content at R6-R7 stage was recorded in genotype MACS-1037(0.90 g/100g). The sugar content at R6-R7 stage varied from 0.90 to 3.43 $\mathrm{g} / 100 \mathrm{~g}$ with mean of $2.92 \mathrm{~g} / 100 \mathrm{~g}$. The total soluble sugar content of the fresh green beans is an important nutritional trait that directly influences the organoleptic properties of vegetable soybean and determines consumer acceptability. The above results are in conformity with the reports of Swathi $(2009)^{[13]}$.

The iron content at R6 stage ranged between 3.24 to 7.12 $\mathrm{mg} / 100 \mathrm{~g}$ and the maximum iron content was noted in AGS$450(7.12 \mathrm{mg} / 100 \mathrm{~g})$ and it was at par with AGS-459 (7.04 $\mathrm{mg} / 100 \mathrm{~g})$, Swarna vasundhara $(6.73 \mathrm{mg} / 100 \mathrm{~g})$ and AGS-457 $(5.82 \mathrm{mg} / 100 \mathrm{~g})$. Whereas, minimum iron content was found in JS-93-05 (3.24 mg/100g). The genotype AGS-450 recorded maximum iron content at R8 stage $(9.79 \mathrm{mg} / 100 \mathrm{~g})$ which was at par with AGS-459 (9.34 mg/100g) and AGS-457 (9.12 $\mathrm{mg} / 100 \mathrm{~g})$. Whereas, minimum iron content was found in JS93-05 (6.79 mg/100g).

The genotype AGS-459 recorded maximum $(6.40 \mathrm{mg} / 100 \mathrm{~g})$ zinc content at R6 stage and was found at par with Himso$1563(6.34 \mathrm{mg} / 100 \mathrm{~g})$, Swarna vasundhara $(6.30 \mathrm{mg} / 100 \mathrm{~g})$ and AGS-450(6.20 mg/100 g) whereas, minimum zinc content was recorded in JS-93-05 $(4.74 \mathrm{mg} / 100 \mathrm{~g})$ and it was varied from 4.74 to $6.40 \mathrm{mg} / 100 \mathrm{~g}$. Maximum zinc content at R8 stage was found in Swarna vasundhara $(5.60 \mathrm{mg} / 100 \mathrm{~g})$ which was at par with AGS-450 (5.43 mg/100g), AGS-339 $(5.34 \mathrm{mg} / 100 \mathrm{~g})$ and AGS-459 $(5.31 \mathrm{mg} / 100 \mathrm{~g})$ whereas, the minimum zinc content was recorded in grain soybean JS-93$05(3.93 \mathrm{mg} / 100 \mathrm{~g})$. Similar results for iron and zinc were reported by Garg et al. (2014) ${ }^{[4]}$.

The trypsin inhibitor content was ranged between 18.29 to $46.26 \mathrm{mg} / \mathrm{g}$ and 33.96 to $75.09 \mathrm{mg} / \mathrm{g}$ at R6 and R8 stage respectively. The genotype AGS-450 had significantly lowest trypsin inhibitor content $(18.29 \mathrm{mg} / \mathrm{g})$ at R6 stage followed by AGS-459 $(23.80 \mathrm{mg} / \mathrm{g})$. However, highest trypsin inhibitor content at R6 stage was observed in genotype GC-84501-3201 (46.26 mg/g) followed by JS-93-05(39.67 mg/g). Minimum trypsin inhibitor content at R8 stage was found in AGS-450(33.96 mg/g) which was at par with AGS-459(34.74 $\mathrm{mg} / \mathrm{g})$. Genotype GC-84501-32-01 recorded highest trypsin inhibitor $(75.09 \mathrm{mg} / \mathrm{g}$ ) followed by NRC-37(70.02 mg/g)). The present results are in accordance with the findings of Shivakumar et al. (2015) in soybean. Trypsin inhibitor activity increased continuously from green pod stage (R6) till harvest maturity (R8), which is in agreement with earlier report (Vineet Kumar et al. 2004) ${ }^{[14]}$ in soybean.

\section{Conclusion}

From the present study it can be concluded that the vegetable type soybean genotypes were more nutritious than grain types in protein, carbohydrate, sugar, iron and zinc. The trypsin inhibitor activity was low in green stage as compared to maturity stage. Swarna vasundhara was found promising for protein content at R6 stage, the genotype AGS-450 exhibited high iron with low trypsin content whereas, AGS-459 exhibited high sugar and zinc content. It is further stated that vegetable types soybean has the potential to meet the nutritional needs of the growing population. 
Table 1: Mean nutritional content of soybean genotypes

\begin{tabular}{|c|c|c|c|c|c|c|}
\hline \multirow{2}{*}{ Genotypes } & \multirow{2}{*}{$\begin{array}{c}\text { Oil content }(\%) \\
\text { R8 } \\
\end{array}$} & \multicolumn{2}{|c|}{ Protein content $(\%)$} & \multicolumn{2}{|c|}{ Carbohydrate content $(\mathrm{g} / \mathbf{1 0 0 g})$} & \multirow{2}{*}{$\begin{array}{c}\text { Sugar content }(\mathrm{g} / \mathbf{1 0 0 g}) \\
\text { R6-R7 } \\
\end{array}$} \\
\hline & & R6 & R8 & R6 & R8 & \\
\hline JS-335 & 20.59 & 21.32 & 36.22 & 10.67 & 26.53 & 1.40 \\
\hline JS(SH) 93-37 & 20.36 & 20.06 & 34.04 & 11.08 & 27.59 & 1.45 \\
\hline JS-93-05 & 19.72 & 18.11 & 35.01 & 9.89 & 24.15 & 0.94 \\
\hline MACS-450 & 19.51 & 18.57 & 36.75 & 10.11 & 24.73 & 1.19 \\
\hline MACS-1037 & 20.03 & 20.71 & 35.02 & 9.23 & 24.41 & 0.90 \\
\hline MACS-1188 & 20.11 & 21.20 & 38.22 & 10.05 & 27.20 & 1.23 \\
\hline NRC-37 & 20.42 & 21.81 & 38.40 & 9.44 & 25.25 & 1.08 \\
\hline Swarna vasundhara & 18.47 & 27.57 & 37.36 & 7.76 & 28.30 & 2.57 \\
\hline GC-84501-32-01 & 19.36 & 25.11 & 36.34 & 7.43 & 25.38 & 2.07 \\
\hline AGS-339 & 19.90 & 20.89 & 32.57 & 8.13 & 26.20 & 2.50 \\
\hline AGS-450 & 17.65 & 23.30 & 37.03 & 8.41 & 24.62 & 2.77 \\
\hline AGS-457 & 17.51 & 22.43 & 37.54 & 8.87 & 26.68 & 3.13 \\
\hline AGS-459 & 18.49 & 21.25 & 38.38 & 9.08 & 28.37 & 3.43 \\
\hline Himso-1563 & 20.01 & 27.55 & 39.09 & 7.70 & 27.37 & 2.16 \\
\hline $\mathrm{SE}(\mathrm{m}+)$ & 0.39 & 0.55 & 0.36 & 0.67 & 0.86 & 0.38 \\
\hline $\mathrm{CD}$ at $\overline{5 \%}$ & 1.13 & 1.59 & 1.04 & 1.95 & 2.50 & 1.09 \\
\hline
\end{tabular}

Table 2: Mean nutritional content of soybean genotypes

\begin{tabular}{|c|c|c|c|c|c|c|}
\hline \multirow{2}{*}{ Genotypes } & \multicolumn{2}{|c|}{ Iron $(\mathrm{mg} / \mathbf{1 0 0 g})$} & \multicolumn{2}{|c|}{ Zinc (mg/100g) } & \multicolumn{2}{|c|}{ Trypsin inhibitor content $(\mathrm{mg} / \mathrm{g})$} \\
\hline & R6 & R8 & R6 & R8 & R6 & R8 \\
\hline JS-335 & 4.51 & 7.80 & 5.11 & 4.61 & 36.59 & 53.15 \\
\hline JS(SH) 93-37 & 3.83 & 7.25 & 4.93 & 4.73 & 31.24 & 62.19 \\
\hline JS-93-05 & 3.24 & 6.79 & 4.74 & 3.93 & 39.67 & 58.64 \\
\hline MACS-450 & 4.13 & 7.74 & 5.02 & 4.30 & 29.45 & 43.18 \\
\hline MACS-1037 & 4.12 & 6.92 & 5.31 & 4.72 & 31.05 & 56.05 \\
\hline MACS-1188 & 4.22 & 7.10 & 5.32 & 4.42 & 32.35 & 50.59 \\
\hline NRC-37 & 3.94 & 7.03 & 5.12 & 4.36 & 25.60 & 70.02 \\
\hline Swarna vasundhara & 6.73 & 8.91 & 6.30 & 5.60 & 34.36 & 52.70 \\
\hline GC-84501-32-01 & 4.91 & 7.84 & 5.31 & 4.89 & 46.26 & 75.09 \\
\hline AGS-339 & 5.24 & 8.24 & 5.70 & 5.34 & 38.14 & 61.25 \\
\hline AGS-450 & 7.12 & 9.79 & 6.20 & 5.43 & 18.29 & 33.96 \\
\hline AGS-457 & 5.82 & 9.12 & 5.54 & 4.81 & 24.92 & 38.31 \\
\hline AGS-459 & 7.04 & 9.34 & 6.40 & 5.31 & 23.80 & 34.74 \\
\hline Himso-1563 & 5.32 & 7.83 & 6.34 & 5.03 & 24.05 & 42.39 \\
\hline $\mathrm{SE}(\mathrm{m}+)$ & 0.49 & 0.19 & 0.16 & 0.11 & 0.99 & 1.24 \\
\hline $\mathrm{CD}$ at $5 \%$ & 1.43 & 0.52 & 0.46 & 0.31 & 2.86 & 3.60 \\
\hline
\end{tabular}

\section{References}

1. Aditya JP, Bhartiya P, Bhartiya A. Genetic variability, heritability and character association for yield and component characters in soybean. Journal of Central European Agriculture. 2011; 12(1):27-34.

2. Anonymous. Statistics, the Soybean Processors Association of India (SOPA), www.sopa. org., 2019.

3. Bradford MM. A rapid sensitive method for the quantification of microgram quantities of protein utilising the principle of protein-Dye Binding. Anal Biochem. 1976; 72:248-254.

4. Garg S, Malik RK, Lule V, Awasti N. Soy and its supplements in combating malnutrition and lifestyle disorders. Journal of Innovative Biology. 2014; 1(3):126131.

5. Gu Weihong, Zheng Wongjion, Zhang Yan, Zhang Guorong. Trends in production, demand and scientific researches on vegetable soybean (Glycine max L. Merill) at home and abroad. Acta Agricalturae Shanghai. 2002; $18: 45-48$.

6. Hamerstrand GE, Black LT, Glover JD. Trypsin inhibitors in soy products; Modification of the standard analytical procedure. Cereal Chemistry. 1981; 58:42-45.

7. Jackson ML. Soil analysis methods as used in Iowa State College, Soil Testing \ Laboratory. Iowa Agric. 1967; 57:1-31.

8. Kakade ML, Rackis JJ, Mc gee JE, Pushki G. Determination of trypsin inhibitor activity of soy products: a collaborative analysis of an improved procedure. Cereal Chemistry. 1974; 51:376-82.

9. Poornima R, Koti RV, Ramakrishnan NM. Physiological basis of yield variation in vegetable soybean and organoleptic test for acceptance. Plant Archives. 2014; 14(1):51-54.

10. Ramya V. Physiological basis of yield variation and consumer acceptability characterization in vegetable soybean (Glycine $\max$ (L.) Merrill), M. Sc. Thesis, University of Agricultural Sciences, Dharwad, 2015.

11. Sengar RS, Chaudhary R. Laboratory manual of biochemistry methods and techniques. Email:info@nipabooks.com, 2014.

12. Shivakumar M, Verma Khushbu, Talukdar Akshay, Srivastava Nidhi, Lal SK, Sapra RL et al. Genetic variability and effect of heat treatment on trypsin inhibitor content in soybean [Glycine max (L.) Merrill.]. Legume Research. 2015; 38(1):60-65.

13. Swathi P. Breeding investigations in vegetable soybean (Glycine max (L.) merrill). Department of genetics and plant breeding, College of Agriculture, University of Agricultural Sciences, Dharwad, 2009.

14. Vineet Kumar, Anita Rani, Chauhan GS. Interrelationship among lipoxygenase isozymes, polyunsaturated fatty acids and trypsin inhibitor during seed development in soybean, Soybean Research. 2004; 2:10-16. 